\title{
ANALISIS KEMAMPUAN SISWA PADA TES PENILAIAN AKHIR SEMESTER MATA PELAJARAN PADB MENGGUNAKAN MODEL RASCH DI SD MA'ARIF NU PANDAAN PASURUAN
}

\author{
Askhabul Kirom ${ }^{1}$, Mochamad Hasyim ${ }^{1}$ \\ ${ }^{1}$ Universitas Yudharta Pasuruan, Pasuruan \\ *Corresponding Address: k1r0m@yudharta.ac.id
}

Naskah diterima: 15 September 2021| Disetujui: 1 Oktober 2021| Diterbitkan: 3 Oktober 2021

\begin{abstract}
The purpose of this study was to determine the student's ability analysis in the PAdB Final Semester Assessment Test using the Rasch Model at Ma'arif Elementary School NU Pandaan Pasuruan. This research is an exploratory descriptive study of the data set of items and student responses in the Final Assessment Test for the PAdB Subject Semester using the Rasch Model at SD Ma'arif NU Pandaan Pasuruan. Research findings: first, high ability is number 3 or the code is 03P1 while the lowest ability is code 57P2. Second, there are 3 students whose answer patterns are considered unfit, namely students with codes 54P2, 37L1, and 32L1, all 3 students are outside the criteria for the level of conformity. In addition, students with codes $(38 \mathrm{L1}, 14 \mathrm{L1})$, in addition to being careless, were detected by students in working on questions that had lucky guesses. This can be seen in the table above, namely for students with code 37L1, where in question number 1 the student is not able to work on the easiest questions, on the other hand the student is able to work on the difficult questions, namely questions on number 14.
\end{abstract}

Keywords: Ability Analysis; Test; Rasch Model

\begin{abstract}
Abstrak: Analisis abilitas siswa digunakan untuk memetakan ability siswa sesuai dengan prestasi hasil pengelompokan, serta untuk mengetahui jika didapati siswa yang pola jawabannya tidak sesuai dengan artian ada ketidaksesuaian jawaban yang diberikan berdasarkan abilitas siswa. Tujuan untuk mengetahui analisis abilitas siswa pada tes Penilaian Akhir Semester mata pelajaran PAdB dengan menggunakan Rasch Model di SD Ma'arif NU Pandaan Pasuruan. Penelitian ini merupakan penelitian deskriptif eksploratif terhadap kumpulan data item dan tanggapan siswa pada Tes Penilaian Akhir Semester Mata Pelajaran PAdB dengan Menggunakan Rasch Model di SD Ma'arif NU Pandaan Pasuruan. Temuan penelitian pertama, abilitas tinggi yaitu nomor 3 atau kodenya 03P1 sedangkan abilitas paling rendah yaitu kode 57P2. Kedua, ada 3 siswa yang pola jawabannya dinilai tidak fit yaitu pada siswa dengan kode 54P2, 37L1, dan 32L1, ke-3 siswa tersebut di luar batas kriteria tingkat kesesuaian. Selain itu siswa kode (38L1, 14L1), di samping tidak cermat (careless), terdeteksi siswa dalam mengerjakan soal terdapat adanya tebakan (lucky guess). Hal ini tampak pada siswa kode 37L1, di mana pada soal nomor 1 siswa tersebut tidak mempu mengerjakan soal yang paling mudah, disisi lain siswa tersebut mampu mengerjakan soal yang sulit yaitu soal pada nomor 14 .
\end{abstract}

Kata kunci: Analisis Abilitas; Tes; Rasch Model 


\section{PENDAHULUAN}

Penilaian dimaknai sebagai upaya penarikan kesimpulan tentang perkembangan atau hasil belajar peserta didik dari sekumpulan data yang didapat melalui pengukuran, baik menggunakan tes maupun non tes yang berkaiatan suatu program pendidikan (Rivale, 2019). Penilaian pendidikan diartikan dengan suatu kegiatan menilai yang akan terjadi dalam pendidikan guna mengetahui apakah usaha yang dilakukan melalui pendidikan sudah tercapai tujuan atau belum. Kaitannya dengan hal ini berfungsi untuk mengetahui seberapa jauh hasil yang telah dicapai dalam proses pendidikan yang telah dilaksanakan ataupun untuk membandingkan prestasi yang dicapai oleh siswa sudah sesuai dengan kapasitasnya atau belum (Maruti, 2016).

Dalam konteks penilaian pendidikan, selain menganalisis butir soal, penting juga menganalisis abilitas siswa dalam menghadapi butir soal ujian yang diberikan. Menganalisis abilitas siswa akan membantu guru untuk membantu siswa belajar lebih efektif. Melalui analisis abilitas siswa, tentunya dapat memetakan kemampuan siswa sesuai kepentingan pengelompokan prestasi, selain itu juga dapat mendeteksi individu yang pola responnya tidak sesuai dengan artian adanya ketidaksesuaian jawaban yang diberikan berdasarkan abilitasnya dibandingkan model ideal. Hal ini digunakan oleh guru untuk mengetahui konsistensi berfikir siswa maupun dapat digunakan untuk mengetahui jika terdapat kecurangan yang dilakukan. respons berbeda, maupun siswa yang diidentifikasi bekerja sama (Bambang Sumintono dan Wahyu Widhiarso, 2015).

Untuk itu Penulis menganggap perlunya diadakan penelitian untuk tingkat abilitas dan tingkat kesesuaian Individu dengan judul "Analisis Abilitas Siswa pada Tes Penilaian Akhir Semester Mata Pelajaran PAdB dengan Menggunakan Rasch Model di SD Ma’arif NU Pandaan Pasuruan”.

\section{METODE}

Penelitian ini merupakan studi deskriptif eksploratif terhadap pengumpulan data item dan respon siswa di SD Ma'arif NU di Kecamatan Pandaan Kabupaten Pasuruan pada semester I mata pelajaran PAdB tahun pelajaran 2020/2021. Penelitian ini menggunakan post-hoc diagnosis, yang ditampilkan sebagai pendekatan retro-fitting. Pendekatan ini dilakukan dengan menganalisis kemampuan siswa pada tes evaluasi semester akhir mata pelajaran PAdB dengan menggunakan pemodelan Rasch.

Subjek dalam hal ini adalah siswa kelas V yang mengikuti tes standarisasi mutu semester I mata pelajaran PAI yang dievaluasi di SD Ma'arif Sumberejo, SDN Ma'arif NU Ngampir, dan SDN Ma'arif Riyadul Arkham Kecamatan Pandaan. Untuk yang dianalisis dalam hal ini yaitu 20 soal pilihan ganda dengan empat pilihan jawaban A, B, C, dan D. 
Pengumpulan data penelitian ini berupa dokumen. Dengan kata lain, data dikumpulkan pada lembar jawaban kelas 5 SD Ma'arif Sumberejo, SD Ma'arif NU Ngampir dan SD Ma'arif Riyadul Arkham di kecamatan Pandaan Kabupaten Pasuruan. Dokumen yang digunakan dalam pengumpulan data untuk penelitian ini adalah lembar soal siswa untuk tes standardisasi mutu sekolah dasar semester I Kelas V mata pelajaran Pendidikan Agama Islam tahun 2020-2021, dan lembar jawaban siswa untuk soal tes standarisasi mutu sekolah dasar semester I mata pelajaran Kelas V mata pelajaran Pendidikan Agama Islam tahun pelajaran 2020-2021.

Analisis data digunakan untuk mengatur dan mengolah data dengan cara yang dapat dimengerti. Analisis data penelitian ini menggunakan Software Ministep. Ministep adalah program komputer yang didedikasikan untuk analisis pemodelan Rasch menggunakan sistem Windows dibuat oleh John linacre.

\section{HASIL DAN PEMBAHASAN}

\section{Analisis Tingkat Abilitas}

Analisis tingkat abilitas atau kemampuan siswa dapat diperoleh dengan melihat menu utama pada Output Table yaitu tabel 1 Person Measure dengan artian tabel yang merinci tentang informasi logit dari tiap siswa.

Tabel 1. Person Measure

\begin{tabular}{|c|c|c|c|c|c|c|c|c|c|c|c|c|c|}
\hline \multirow{2}{*}{$\begin{array}{c}\text { Entry } \\
\text { Number }\end{array}$} & \multirow{2}{*}{$\begin{array}{l}\text { Total } \\
\text { Score }\end{array}$} & \multirow{2}{*}{$\begin{array}{l}\text { Total } \\
\text { Count }\end{array}$} & \multirow[t]{2}{*}{ Measure } & \multirow{2}{*}{$\begin{array}{l}\text { Model } \\
\text { S.E. }\end{array}$} & \multicolumn{2}{|c|}{ Infit } & \multicolumn{2}{|c|}{ Outfit } & \multicolumn{2}{|c|}{$\begin{array}{c}\text { PT- } \\
\text { Measure }\end{array}$} & \multicolumn{2}{|c|}{ Exact Match } & \multirow[t]{2}{*}{ Person } \\
\hline & & & & & MNSQ & $\mathrm{ZSTD}$ & MNSQ & STD & CORR. & EXP. & OBS\% & EXP\% & \\
\hline 3 & 20 & 20 & 5.14 & 1.86 & \multicolumn{4}{|c|}{ Maximum Measure } & .00 & .00 & 100.0 & 100.0 & 03P1 \\
\hline 26 & 20 & 20 & 5.14 & 1.86 & \multicolumn{4}{|c|}{ Maximum Measure } & .00 & .00 & 100.0 & 100.0 & $26 \mathrm{P} 1$ \\
\hline 39 & 20 & 20 & 5.14 & 1.86 & \multicolumn{4}{|c|}{ Maximum Measure } & .00 & .00 & 100.0 & 100.0 & 39P1 \\
\hline 2 & 19 & 20 & 3.83 & 1.07 & .98 & 03 & .36 & -.1 & .29 & .24 & 95.0 & 95.0 & 02P1 \\
\hline 9 & 19 & 20 & 3.83 & 1.07 & .69 & -.1 & .18 & -.5 & .42 & .24 & 95.0 & 95.0 & 09P1 \\
\hline 15 & 19 & 20 & 3.83 & 1.07 & .69 & -.1 & .18 & -.5 & .42 & .24 & 95.0 & 95.0 & 15P1 \\
\hline 31 & 19 & 20 & 3.83 & 1.07 & .98 & .3 & .36 & -.1 & .29 & .24 & 95.0 & 95.0 & 31P1 \\
\hline 36 & 19 & 20 & 3.83 & 1.07 & 1.24 & .6 & 2.10 & 1.1 & .02 & .24 & 95.0 & 95.0 & 36P1 \\
\hline 61 & 19 & 20 & 3.83 & 1.07 & .69 & -.1 & .18 & -.5 & .42 & .24 & 95.0 & 95.0 & 61P3 \\
\hline 1 & 18 & 20 & 2.99 & .81 & 1.01 & .2 & .45 & .0 & .38 & .33 & 90.0 & 90.0 & 01P1 \\
\hline 6 & 18 & 20 & 2.99 & .81 & .69 & -.5 & .29 & -.2 & .50 & .33 & 90.0 & 90.0 & 06P1 \\
\hline 10 & 18 & 20 & 2.99 & .81 & 1.32 & .7 & 1.20 & .6 & .16 & .33 & 90.0 & 90.0 & 10L1 \\
\hline 13 & 18 & 20 & 2.99 & .81 & .83 & -.2 & .46 & .0 & .43 & .33 & 90.0 & 90.0 & 13L1 \\
\hline 27 & 18 & 20 & 2.99 & .81 & .84 & -.2 & .48 & .0 & .42 & .33 & 90.0 & 90.0 & $27 \mathrm{P} 1$ \\
\hline 33 & 18 & 20 & 2.99 & .81 & .74 & -.4 & .33 & -.2 & .48 & .33 & 90.0 & 90.0 & 33P1 \\
\hline 42 & 18 & 20 & 2.99 & .81 & .80 & -.2 & .41 & -.1 & .44 & .33 & 90.0 & 90.0 & 42P2 \\
\hline 44 & 18 & 20 & 2.99 & .81 & .80 & -.2 & .41 & -.1 & .44 & .33 & 90.0 & 90.0 & 44P2 \\
\hline 65 & 18 & 20 & 2.99 & .81 & .93 & .0 & .39 & -.1 & .41 & .33 & 90.0 & 90.0 & $65 \mathrm{P} 3$ \\
\hline 66 & 18 & 20 & 2.99 & .81 & .80 & -.2 & .41 & -.1 & .44 & .33 & 90.0 & 90.0 & 66P3 \\
\hline 67 & 18 & 20 & 2.99 & .81 & .93 & .0 & .39 & -.1 & .41 & .33 & 90.0 & 90.0 & 67P3 \\
\hline 7 & 17 & 20 & 2.43 & .70 & 1.05 & .3 & .55 & .0 & .42 & .39 & 80.0 & 85.9 & 07P1 \\
\hline 16 & 17 & 20 & 2.43 & .70 & .92 & -.1 & .54 & .0 & .46 & .39 & 90.0 & 85.9 & 16L1 \\
\hline 20 & 17 & 20 & 2.43 & .70 & 1.56 & 1.4 & 1.75 & .9 & .08 & .39 & 80.0 & 85.9 & 20L1 \\
\hline 21 & 17 & 20 & 2.43 & .70 & 1.13 & .5 & .82 & .3 & .35 & .39 & 80.0 & 85.9 & 21L1 \\
\hline
\end{tabular}




\begin{tabular}{|c|c|c|c|c|c|c|c|c|c|c|c|c|c|}
\hline 23 & 17 & 20 & 2.43 & .70 & 1.13 & .5 & .82 & .3 & .35 & .39 & 80.0 & 85.9 & $23 \mathrm{~L} 1$ \\
\hline 28 & 17 & 20 & 2.43 & .70 & 1.21 & .6 & 1.31 & .6 & .27 & .39 & 80.0 & 85.9 & 28P1 \\
\hline 30 & 17 & 20 & 2.43 & .70 & .68 & -.8 & .34 & -.3 & .57 & .39 & 90.0 & 85.9 & 30P1 \\
\hline 40 & 17 & 20 & 2.43 & .70 & .89 & -.1 & .58 & .0 & .46 & .39 & 90.0 & 85.9 & $40 \mathrm{P} 2$ \\
\hline 59 & 17 & 20 & 2.43 & .70 & .97 & .1 & .51 & .0 & .45 & .39 & 80.0 & 85.9 & $59 \mathrm{P} 3$ \\
\hline 62 & 17 & 20 & 2.43 & .70 & 1.03 & .2 & .79 & .3 & .38 & .39 & 90.0 & 85.9 & $62 \mathrm{P} 3$ \\
\hline 2 & 16 & 20 & 1.99 & .64 & .93 & -.1 & .65 & -.1 & .49 & .44 & 80.0 & 81.9 & 05P1 \\
\hline 22 & 16 & 20 & $\begin{array}{l}1.99 \\
\end{array}$ & .64 & .79 & $\begin{array}{l}-.6 \\
\end{array}$ & .46 & -.3 & .57 & .44 & 80.0 & 81.9 & $22 \mathrm{~L} 1$ \\
\hline 24 & 16 & 20 & 1.99 & .64 & .82 & -.5 & .82 & .1 & .51 & .44 & 90.0 & 81.9 & $24 \mathrm{~L} 1$ \\
\hline 29 & 16 & 20 & 1.99 & .64 & 1.27 & .9 & 1.11 & .4 & .31 & .44 & 80.0 & 81.9 & 29P1 \\
\hline 38 & 16 & 20 & $\begin{array}{l}1.99 \\
\end{array}$ & .64 & 1.53 & 1.5 & 2.79 & 1.5 & .10 & .44 & 70.0 & 81.9 & $38 \mathrm{~L} 1$ \\
\hline 41 & 16 & 20 & 1.99 & .64 & .93 & -.1 & .59 & -.1 & .50 & .44 & 80.0 & 81.9 & $41 \mathrm{P} 2$ \\
\hline 63 & 16 & 20 & 1.99 & .64 & .67 & -1.1 & .38 & -.5 & .62 & .44 & 90.0 & 81.9 & $63 \mathrm{P} 3$ \\
\hline 78 & 16 & 20 & 1.99 & .64 & .62 & -1.2 & .36 & -.5 & .64 & .44 & 90.0 & 81.9 & $78 \mathrm{~L} 3$ \\
\hline 81 & 16 & 20 & 1.99 & .64 & .66 & -1.1 & .39 & -.5 & .62 & .44 & 90.0 & 81.9 & 81P3 \\
\hline 4 & 15 & 20 & 1.61 & .60 & .86 & $\begin{array}{l}.4 \\
\end{array}$ & .61 & -.3 & .56 & .48 & 85.0 & 79.4 & 04L1 \\
\hline 11 & 15 & 20 & 1.61 & .60 & .89 & $\begin{array}{l}-.3 \\
\end{array}$ & .79 & .0 & .53 & .48 & 85.0 & 79.4 & $11 \mathrm{~L} 1$ \\
\hline 14 & 15 & 20 & 1.61 & .60 & 1.37 & 1.2 & 2.09 & 1.3 & .24 & .48 & 75.0 & 79.4 & 14L1 \\
\hline 19 & 15 & 20 & 1.61 & .60 & .57 & -1.7 & .36 & -.8 & .70 & .48 & 95.0 & 79.4 & 19P1 \\
\hline 35 & 15 & 20 & 1.61 & .60 & .67 & -1.2 & .42 & -.6 & .66 & .48 & 85.0 & 79.4 & $35 \mathrm{~L} 1$ \\
\hline 58 & 15 & 20 & 1.61 & .60 & 1.00 & .1 & .70 & -.1 & .51 & .48 & 75.0 & 79.4 & $58 \mathrm{~L} 2$ \\
\hline 64 & 15 & 20 & 1.61 & .60 & .79 & -.7 & .51 & -.4 & .61 & .48 & 85.0 & 79.4 & $64 \mathrm{P} 3$ \\
\hline 71 & 15 & 20 & 1.61 & .60 & .90 & $\begin{array}{l}-.3 \\
\end{array}$ & .64 & \begin{tabular}{|c|}
-.2 \\
\end{tabular} & .55 & .48 & 75.0 & 79.4 & $71 \mathrm{~L} 3$ \\
\hline 18 & 14 & 20 & 1.26 & .58 & 1.27 & 1.0 & 1.02 & .3 & .40 & .51 & 65.0 & 77.5 & $18 \mathrm{~L} 1$ \\
\hline 37 & 14 & 20 & 1.26 & .58 & 1.60 & 2.0 & 3.28 & 2.3 & .12 & .51 & 65.0 & 77.5 & $37 \mathrm{~L} 1$ \\
\hline 72 & 14 & 20 & 1.26 & .58 & .96 & -.1 & .68 & -.3 & .56 & .51 & 75.0 & 77.5 & $72 \mathrm{P} 3$ \\
\hline 74 & 14 & 20 & 1.26 & .58 & .96 & -.1 & .68 & -.3 & .56 & .51 & 75.0 & 77.5 & $74 \mathrm{P} 3$ \\
\hline 8 & 13 & 20 & .94 & .56 & 076 & -.9 & .55 & \begin{tabular}{|l|}
-.7 \\
\end{tabular} & .67 & .53 & 80.0 & 79.7 & 08P1 \\
\hline 12 & 13 & 20 & .94 & .56 & 1.10 & .5 & .80 & -.2 & .52 & .53 & 60.0 & 79.7 & $12 \mathrm{P} 1$ \\
\hline 25 & 13 & 20 & .94 & .56 & .85 & -.5 & .64 & -.5 & .63 & .53 & 80.0 & 79.7 & $25 \mathrm{~L} 1$ \\
\hline 34 & 13 & 20 & .94 & .56 & 1.15 & .7 & 1.14 & .4 & .45 & .53 & 80.0 & 79.7 & $34 \mathrm{P} 1$ \\
\hline 60 & 13 & 20 & .94 & .56 & .90 & -.3 & .75 & $\begin{array}{l}-.3 \\
\end{array}$ & .59 & .53 & 80.0 & 79.7 & $60 \mathrm{L3}$ \\
\hline 73 & 13 & 20 & .94 & .56 & .60 & -1.7 & .44 & -1.0 & .74 & .53 & 90.0 & 79.7 & $73 \mathrm{L3}$ \\
\hline 75 & 13 & 20 & .94 & .56 & .97 & .0 & .79 & -.2 & .56 & .53 & 80.0 & 79.7 & $75 \mathrm{~L} 3$ \\
\hline 76 & 13 & 20 & .94 & .56 & .97 & .0 & .79 & -.2 & .56 & .53 & 80.0 & 79.7 & $76 \mathrm{L3}$ \\
\hline 77 & 13 & 20 & .94 & .56 & .68 & $\begin{array}{l}-1.3 \\
\end{array}$ & .50 & \begin{tabular}{|l|}
-.9 \\
\end{tabular} & .71 & .53 & 90.0 & 79.7 & $77 \mathrm{L3}$ \\
\hline 79 & 13 & 20 & .94 & .56 & .97 & .0 & .79 & -.2 & .56 & .53 & 80.0 & 79.7 & 79L3 \\
\hline 80 & 13 & 20 & .94 & .56 & .71 & -1.2 & .51 & -.8 & .70 & .53 & 80.0 & 79.7 & $80 \mathrm{P} 3$ \\
\hline 17 & 12 & 20 & .63 & .55 & .69 & -1.2 & .52 & \begin{tabular}{|c|}
-1.0 \\
\end{tabular} & .72 & .55 & 85.0 & 76.0 & $17 \mathrm{~L} 1$ \\
\hline 68 & 12 & 20 & .63 & .55 & .60 & -1.7 & .45 & -1.2 & .76 & .55 & 85.0 & 76.0 & $68 \mathrm{L3}$ \\
\hline 39 & 12 & 20 & .63 & .55 & 1.08 & .4 & .91 & .0 & .53 & .55 & 75.0 & 76.0 & 69L3 \\
\hline 47 & 11 & 20 & .33 & .55 & 1.03 & .2 & .91 & $\begin{array}{ll}-.1 \\
\end{array}$ & .56 & .56 & 65.0 & 75.5 & $47 \mathrm{~L} 2$ \\
\hline 45 & 10 & 20 & .03 & .55 & 1.32 & 1.2 & 1.09 & .3 & .45 & .57 & 55.0 & 75.7 & $45 \mathrm{P} 2$ \\
\hline 46 & 10 & 20 & .03 & .55 & .88 & -.4 & .86 & -.2 & .63 & .57 & 85.0 & 75.7 & $46 \mathrm{~L} 2$ \\
\hline 48 & 10 & 20 & .03 & .55 & .62 & -1.6 & .50 & \begin{tabular}{|l|}
-1.3 \\
\end{tabular} & .77 & .57 & 95.0 & 75.7 & $48 \mathrm{~L} 2$ \\
\hline 52 & 10 & 20 & .03 & .55 & 1.12 & .5 & 1.53 & 1.2 & .48 & .57 & 75.0 & 75.7 & $52 \mathrm{P} 2$ \\
\hline 43 & 9 & 20 & -.27 & .55 & 1.62 & 2.0 & 1.62 & 1.3 & .27 & .57 & 50.0 & 76.2 & $43 \mathrm{P} 2$ \\
\hline 53 & 9 & 20 & -.27 & .55 & 1.26 & 1.0 & 1.03 & .2 & .48 & .57 & 60.0 & 76.2 & $53 \mathrm{P} 2$ \\
\hline 55 & 9 & 20 & -.27 & .55 & 1.02 & .2 & 1.90 & 1.8 & .49 & .57 & 80.0 & 76.2 & $55 \mathrm{~L} 2$ \\
\hline 56 & 9 & 20 & -.27 & .55 & .66 & -1.3 & .56 & -1.1 & .75 & .57 & 90.0 & 76.2 & $56 \mathrm{~L} 2$ \\
\hline 49 & 8 & 20 & $\begin{array}{l}-.58 \\
\end{array}$ & .56 & 1.45 & .6 & 2.18 & 2.0 & .44 & .57 & 75.0 & 76.8 & 49L2 \\
\hline 51 & 8 & 20 & -.58 & .56 & 1.46 & 1.6 & 1.70 & 1.4 & .32 & .57 & 65.0 & 76.8 & $51 \mathrm{~L} 2$ \\
\hline 32 & 6 & 20 & -1.23 & .59 & 2.02 & 2.7 & 3.12 & 2.4 & -.06 & .55 & 65.0 & 79.2 & $32 \mathrm{~L} 1$ \\
\hline 50 & 6 & 20 & -1.23 & .59 & 1.43 & 1.4 & 1.38 & .7 & .34 & .55 & 65.0 & 79.2 & $50 \mathrm{~L} 2$ \\
\hline 54 & 6 & 20 & -1.23 & .59 & 1.39 & 1.3 & 4.10 & 3.0 & .21 & .55 & 75.0 & 79.2 & $54 \mathrm{P} 2$ \\
\hline 70 & 6 & 20 & -1.23 & .59 & 1.64 & 1.9 & 1.37 & .7 & .27 & .55 & 65.0 & 79.2 & $70 \mathrm{L3}$ \\
\hline 57 & 5 & 20 & -1.59 & .62 & 1.27 & .9 & 1.07 & .4 & .40 & .52 & 75.0 & 81.1 & $57 \mathrm{P} 2$ \\
\hline MEAN & 14.5 & 20.0 & 1.67 & .71 & .99 & .1 & .90 & .1 & & & 81.5 & 82.1 & \\
\hline S.D & 3.8 & .0 & 1.50 & .27 & .29 & .9 & .73 & .8 & & & 10.3 & 6.0 & \\
\hline
\end{tabular}


Pada kolom entry number adalah nomor urut siswa, kode siswa bisa dilihat pada kolom paling kanan yaitu (person) yang dimulai dari tingkat abilitas tinggi yaitu nomor 3 (tiga) atau kodenya 03P1 untuk abilitas paling rendah yaitu kode 57P2. Hal ini sesuai dengan kolom skor total (total score), yaitu yang menunjukkan jumlah jawaban siswa yang benar. Seperti hanlnya untuk kode 03P1 di mana nilai logit-nya sebesar $+5,41$ logit, siswa tersebut mampu mengerjakan soal dengan benar sebanyak 20 dari 20 soal yang telah diberikan. Bandingkan dengan siswa pada kode 57P2 yang mempunyai nilai logit adalah -1,59 hanya mampu menjawab dengan benar 5 dari 20 soal yang telah diberikan.

Dengan diketahui nilai standar deviasi (SD), maka informasi tersebut bisa digunakan sebagai pengelompokan tingkat abilitas siswa. Semisal, pengelompokan bisa dalam tiga kelompok siswa, tingkat abilitas tinggi, sedang, rendah, dan titik tolak bisa dari nilai rata-rata logit person, yaitu (-0,25 logit) yang tidak lain pengelompokan ini mirip dengan aplikasi penilaian acuan penilaian normatif.

Hal tersebut juga dapat memberikan informasi untuk pengelompokan item kesulitan butir soal (Item Measure) dengan memeriksa nilai standar deviasi $(1,67)$. Menggabungkan nilai ini dengan nilai rata-rata berarti ada empat kelompok kemampuan siswa, tergantung pada tingkat kesulitan itemnya. Dalam hal ini, kemampuan siswa dikelompokkan menjadi empat kelompok.

Pada Item Measure juga dapat memberikan informasi untuk pengelompokan item kesulitan butir soal (Item Measure) dengan memeriksa nilai standar deviasi (1,67). Menggabungkan nilai ini dengan nilai rata-rata berarti ada empat kelompok kemampuan siswa, tergantung pada tingkat kesulitan itemnya. Dalam hal ini, kemampuan siswa dikelompokkan menjadi empat kelompok. (sangat mampu, mampu, tidak mampu, dan kurang mampu). Kelompok butir soal kategori tingkatan sangat mampu pada soal (03P1, 26P1, 39P1, 02P1, 09P1, 15P1, 31P1, 36P1, 61P3, 01P1, 06P1, 10L1, 13L1, 27P1, 33P1, 42P2, 44P2, 65P3, 66P3, 67P3, 07P1, 16L1, 20L1, 21L1, 23L1, 28P1, 30P1, 40P2, 59P3, 62P3, 05P1, 22L1, 24L1, 29P1, 38L1, 41P2, 63P3, 78L3, 81P3, 04L1, 11L1, 14L1, 19P1, 35L1, 58L2, 64P3, 71L3, 18L1, 37L1, 72P3, dan 74P3) dengan ketentuan (lebih besar dari +1SD), untuk kelompok butir soal mampu pada soal (08P1, 12P1, 25L1, 34P1, 60L3, 73L3, 75L3, 76L3, 77L3, 79L3, 80P3, 17L1, 68L3, 69L3, 47L2, 45P2, 46L2, 48L2, dan 52P2) dengan ketentuan (0,0 logit+1SD). Tingkat pengelompokan kurang mampu pada pengerjakan soal (43P2, 53P2, 55L2, 56L2, 49L2, dan 51L2) dengan ketentuan (0,0 Logit-1SD), sedangkan pengelompokan tidak mampu terdapat pada kode siswa (32L1, 50L2, 54P2, 70L3, dan 57P2) dengan ketentuan (lebih kecil dari 1SD).

\section{Tingkat Kesesuaian Individu (Person Fit)}

Selain bisa mengetahui tingkat kemampuan siswa pemodelan Rasch ini juga bisa mengetahui tingkat kesesuaian jawaban siswa yang diperoleh berdasarkan tingkat abilitas siswa. Seperti halnya 
dalam melihat Item Fit untuk menjelaskan butir soal berfungsi untuk mengetahui tingkat kesesuaian pada butir soal secara normal ataupun tidak (Kirom \& Hasyim, 2021). Kriteria yang digunakan untuk memeriksa kesesuaian jawaban butir soal yang tidak sesuai (outliers atau misfits) adalah:

a. Outfit mean square (MNSQ) yang bisa diterima: 0,5 $<$ MNSQ $<1,5$

b. Outfit z-standard (ZSTD) yang bisa diterima: $-2,0<$ ZSTD $<+2,0$

c. Point measure correlation (Pt Mean Corr): 0,4 < Pt Measure Corr < 0,85 (Boone et al., 2013)

Tabel yang menampilkan hal ini dari menu utama Output Tables, dipilih untuk dimunculkan Tabel 2 Person Fit Order. Tabel tersebut akan memunculkan secara berurutan butir soal yang mempunyai kriteria tidak fit sebagaimana berikut:

Tabel 2. Person Fit Order

\begin{tabular}{|c|c|c|c|c|c|c|c|c|c|c|c|c|c|}
\hline \multirow{2}{*}{$\begin{array}{c}\text { Entry } \\
\text { Number }\end{array}$} & \multirow{2}{*}{$\begin{array}{l}\text { Total } \\
\text { Score }\end{array}$} & \multirow{2}{*}{$\begin{array}{l}\text { Total } \\
\text { Count }\end{array}$} & \multirow{2}{*}{ Measure } & \multirow{2}{*}{$\begin{array}{l}\text { Model } \\
\text { S.E. }\end{array}$} & \multicolumn{2}{|c|}{ Infit } & \multicolumn{2}{|c|}{ Outfit } & \multicolumn{2}{|c|}{$\begin{array}{c}\text { PT- } \\
\text { Measure }\end{array}$} & \multicolumn{2}{|c|}{ Exact Match } & \multirow{2}{*}{ Person } \\
\hline & & & & & MNSQ & ZSTD & MNSQ & ZSTD & CORR. & EXP. & OBS $\%$ & EXP\% & \\
\hline 54 & 6 & 20 & -1.23 & .59 & 1.39 & 1.3 & 4.10 & 3.0 & A.21 & .55 & 75.0 & 79.2 & $54 \mathrm{P} 2$ \\
\hline 37 & 14 & 20 & 1.26 & .58 & 1.60 & 2.0 & 3.28 & 2.3 & B. 12 & .51 & 65.0 & 77.5 & $37 \mathrm{~L} 1$ \\
\hline 32 & 6 & 20 & -1.23 & .59 & 2.02 & 2.7 & 3.12 & 2.4 & C.06 & .55 & 65.0 & 79.2 & 32L1 \\
\hline 38 & 16 & 20 & 1.99 & .64 & 1.53 & 1.5 & 2.79 & 1.5 & D. 10 & .44 & 70.0 & 81.9 & 38L1 \\
\hline 49 & 8 & 20 & -.58 & .56 & 1.15 & .6 & 2.18 & 2.0 & E.44 & .57 & 75.0 & 76.8 & 49L2 \\
\hline 36 & 19 & 20 & 3.83 & 1.07 & 1.24 & .6 & 2.10 & 1.1 & F.02 & .24 & 95.0 & 95.0 & $36 \mathrm{P} 1$ \\
\hline 14 & 15 & 20 & 1.61 & .60 & 1.37 & 1.2 & 2.09 & 1.3 & G.24 & .48 & 75.0 & 79.4 & 14L1 \\
\hline 55 & 9 & 20 & . -27 & .55 & 1.02 & .2 & 1.90 & 1.8 & H.49 & .57 & 80.0 & 76.2 & $55 \mathrm{~L} 2$ \\
\hline 20 & 17 & 20 & 2.43 & .70 & 1.56 & 1.4 & 1.75 & .9 & I. .08 & .39 & 80.0 & 85.9 & 20L1 \\
\hline 51 & 8 & 20 & -.58 & .56 & 1.46 & 1.6 & 1.70 & 1.4 & J .32 & .57 & 65.0 & 76.8 & $51 \mathrm{~L} 2$ \\
\hline 70 & 6 & 20 & -1.23 & .59 & 1.64 & 1.9 & 1.37 & .7 & K.27 & .55 & 65.0 & 79.2 & $70 \mathrm{~L} 3$ \\
\hline 43 & 9 & 20 & -.27 & .55 & 1.62 & 2.0 & 1.62 & 1.3 & L .27 & .57 & 50.0 & 76.2 & 43P2 \\
\hline 52 & 10 & 20 & .03 & .55 & 1.12 & .5 & 1.53 & 1.2 & M.48 & .57 & 75.0 & 75.7 & $52 \mathrm{P} 2$ \\
\hline 50 & 6 & 20 & -1.23 & .59 & 1.43 & 1.4 & 1.38 & .7 & N.34 & .55 & 65.0 & 79.2 & $50 \mathrm{~L} 2$ \\
\hline 10 & 18 & 20 & 2.99 & .81 & 1.32 & .7 & 1.20 & .6 & 0.16 & .33 & 90.0 & 90.0 & 10L1 \\
\hline 45 & 10 & 20 & .03 & .55 & 1.32 & 1.2 & 1.09 & .3 & P.45 & .57 & 55.0 & 75.7 & $45 \mathrm{P} 2$ \\
\hline 28 & 17 & 20 & 2.43 & .70 & 1.21 & .6 & 1.31 & .6 & Q .27 & .39 & 80.0 & 85.9 & 28P1 \\
\hline 57 & 5 & 20 & -1.59 & .62 & 1.27 & .9 & 1.07 & .4 & R.40 & .52 & 75.0 & 81.1 & $57 \mathrm{P} 2$ \\
\hline 18 & 14 & 20 & 1.26 & .58 & 1.27 & 1.0 & 1.02 & .3 & S .40 & .51 & 65.0 & 77.5 & 18L1 \\
\hline 29 & 16 & 20 & 1.99 & .64 & 1.27 & .9 & 1.11 & .4 & T.31 & .44 & 80.0 & 81.9 & 29P1 \\
\hline 53 & 9 & 20 & -.27 & .55 & 1.26 & 1.0 & 1.03 & .2 & $\mathrm{U} .48$ & .57 & 60.0 & 76.2 & $53 \mathrm{P} 2$ \\
\hline 34 & 13 & 20 & .94 & .56 & 1.15 & .7 & 1.14 & .4 & $\mathrm{~V} .45$ & .53 & 80.0 & 76.7 & 34P1 \\
\hline 21 & 17 & 20 & 2.43 & .70 & 1.13 & .5 & .82 & .3 & W .35 & .39 & 80.0 & 85.9 & 21L1 \\
\hline 23 & 17 & 20 & 2.43 & .70 & 1.13 & .5 & .82 & .3 & $\mathrm{X} .35$ & .39 & 80.0 & 85.9 & $23 \mathrm{~L} 1$ \\
\hline 12 & 13 & 20 & .94 & .56 & 1.10 & .5 & .80 & -.2 & Y.52 & .53 & 60.0 & 76.7 & 12P1 \\
\hline 69 & 12 & 20 & .63 & .55 & 1.08 & .4 & .91 & .0 & Z.53 & .55 & 75.0 & 76.0 & 69L3 \\
\hline 7 & 17 & 20 & 2.43 & .70 & 1.05 & .3 & .55 & .0 & .42 & .39 & 80.0 & 85.9 & 07P1 \\
\hline 62 & 17 & 20 & 2.43 & .70 & 1.03 & .2 & .79 & .3 & .38 & .39 & 90.0 & 85.9 & $62 \mathrm{P} 3$ \\
\hline 1 & 18 & 20 & 2.99 & .81 & 1.01 & .2 & .45 & .0 & .38 & .33 & 90.0 & 90.0 & 01P1 \\
\hline 58 & 15 & 20 & 1.61 & .60 & 1.00 & .1 & .70 & -.1 & .51 & .48 & 75.0 & 79.4 & 58L2 \\
\hline 2 & 19 & 20 & 3.83 & 1.07 & .98 & .3 & .36 & $\begin{array}{l}-.1 \\
\end{array}$ & .29 & .24 & \begin{tabular}{|l|}
95.0 \\
\end{tabular} & 95.0 & 02P1 \\
\hline 31 & 19 & 20 & 3.83 & 1.07 & .98 & .3 & .36 & -.1 & .29 & .24 & 95.0 & 95.0 & 31P1 \\
\hline \multicolumn{14}{|c|}{ BETTER FITTING OMITTED } \\
\hline 75 & 13 & 20 & .94 & .56 & .97 & .0 & .79 & -.2 & .56 & .53 & 80.0 & 76.7 & $75 \mathrm{~L} 3$ \\
\hline 76 & 13 & 20 & .94 & .56 & .97 & .0 & .79 & -.2 & .56 & .53 & 80.0 & 76.7 & 76L3 \\
\hline 79 & 13 & 20 & .94 & .56 & .97 & .0 & .79 & -.2 & .56 & .53 & 80.0 & 76.7 & 79L3 \\
\hline 59 & 17 & 20 & 2.43 & .70 & .97 & .1 & .51 & .0 & .45 & .39 & 80.0 & 85.9 & $59 \mathrm{P} 3$ \\
\hline
\end{tabular}




\begin{tabular}{|c|c|c|c|c|c|c|c|c|c|c|c|c|c|}
\hline 72 & 14 & 20 & 1.26 & .58 & .96 & $\begin{array}{l}-.1 \\
\end{array}$ & .68 & -.3 & .56 & .51 & 75.0 & 77.5 & $72 \mathrm{P} 3$ \\
\hline 74 & 14 & 20 & 1.26 & .58 & .96 & -.1 & .68 & -.3 & .56 & .51 & 75.0 & 77.5 & $74 \mathrm{P} 3$ \\
\hline 41 & 16 & 20 & 1.99 & .64 & .93 & -.1 & .59 & -.1 & .50 & .44 & 80.0 & 81.9 & $41 \mathrm{P} 2$ \\
\hline 65 & 18 & 20 & 2.99 & .81 & .93 & .0 & .39 & -.1 & .41 & .33 & 90.0 & 90.0 & $65 \mathrm{P} 3$ \\
\hline 67 & 18 & 20 & 2.99 & .81 & .93 & .0 & .39 & -.1 & .41 & .33 & 90.0 & 90.0 & $67 \mathrm{P} 3$ \\
\hline 5 & 16 & 20 & 1.99 & .64 & .93 & -.1 & .65 & -.1 & .49 & .44 & 80.0 & 81.9 & 05P1 \\
\hline 16 & 17 & 20 & 2.43 & .70 & .92 & -.1 & .54 & .0 & .46 & .39 & 90.0 & 85.9 & $16 \mathrm{~L} 1$ \\
\hline 71 & 15 & 20 & 1.61 & .60 & .90 & -.3 & .64 & -.2 & .55 & .48 & 75.0 & 79.4 & $71 \mathrm{L3}$ \\
\hline 60 & 13 & 20 & .94 & .56 & .90 & -.3 & .75 & -.3 & .59 & .53 & 80.0 & 76.7 & $60 \mathrm{L3}$ \\
\hline 40 & 17 & 20 & 2.43 & .70 & .89 & -.1 & .56 & .0 & .46 & .39 & 90.0 & 85.9 & $40 \mathrm{P} 2$ \\
\hline 11 & 15 & 20 & 1.61 & .60 & .89 & -.3 & .79 & .0 & .53 & .48 & 85.0 & 79.4 & $11 \mathrm{~L} 1$ \\
\hline 4 & 15 & 20 & 1.61 & .60 & .86 & $\begin{array}{l}-.4 \\
\end{array}$ & .61 & -.3 & .56 & .48 & 85.0 & 79.4 & 04L1 \\
\hline 25 & 13 & 20 & .94 & .56 & .85 & -.5 & .64 & -.5 & .63 & .53 & 80.0 & 76.7 & $25 \mathrm{~L} 1$ \\
\hline 27 & 18 & 20 & 2.99 & .81 & .84 & -.2 & .48 & .0 & .42 & .33 & 90.0 & 90.0 & $27 \mathrm{P} 1$ \\
\hline 13 & 18 & 20 & 2.99 & .81 & .83 & -.2 & .46 & .0 & $\mathrm{z} .43$ & .33 & 90.0 & 90.0 & $13 \mathrm{~L} 1$ \\
\hline 24 & 16 & 20 & $\begin{array}{l}1.99 \\
\end{array}$ & .64 & .82 & -.5 & .82 & -.1 & y.51 & .44 & 90.0 & $\begin{array}{l}81.9 \\
\end{array}$ & $24 \mathrm{~L} 1$ \\
\hline 42 & 18 & 20 & 2.99 & .81 & .80 & -.2 & .41 & -.1 & $\times .44$ & .33 & 90.0 & 90.0 & $42 \mathrm{P} 2$ \\
\hline 44 & 18 & 20 & 2.99 & .81 & .80 & -.2 & .41 & -.1 & w. .44 & .33 & 90.0 & 90.0 & $44 \mathrm{P} 2$ \\
\hline 66 & 18 & 20 & 2.99 & .81 & .80 & -.2 & .41 & -.1 & v. 44 & .33 & 90.0 & 90.0 & $66 \mathrm{P} 3$ \\
\hline 64 & 15 & 20 & 1.61 & .60 & .79 & -.7 & .51 & -.4 & u .61 & .48 & 85.0 & 79.4 & $64 \mathrm{P} 3$ \\
\hline 22 & 16 & 20 & 1.99 & .64 & .79 & -.6 & .46 & -.3 & $\mathrm{t} .57$ & .44 & 80.0 & 81.9 & $22 \mathrm{L1}$ \\
\hline 8 & 13 & 20 & .94 & .56 & .76 & -.9 & .55 & -.7 & s.67 & .53 & 80.0 & 76.7 & 08P1 \\
\hline 33 & 18 & 20 & 2.99 & .81 & .74 & -.4 & .33 & -.2 & r . 48 & .33 & 90.0 & 90.0 & $33 \mathrm{P} 1$ \\
\hline 80 & 13 & 20 & .94 & .56 & .71 & -1.2 & .51 & -.8 & q. 70 & .53 & 80.0 & 76.7 & $80 \mathrm{P} 3$ \\
\hline 17 & 12 & 20 & .63 & .55 & .69 & -1.2 & .52 & -1.0 & p. 72 & .55 & 85.0 & 76.0 & $17 \mathrm{~L} 1$ \\
\hline 6 & 18 & 20 & 2.99 & .81 & .69 & -.5 & .29 & -.2 & o. .50 & .33 & 90.0 & 90.0 & 06P1 \\
\hline 9 & 19 & 20 & 3.83 & 1.07 & .69 & -.1 & .18 & -.5 & $\mathrm{n} .42$ & .24 & 95.0 & 95.0 & 09P1 \\
\hline 15 & 19 & 20 & 3.83 & 1.07 & .69 & -.1 & .18 & -.5 & m.42 & .24 & 95.0 & 95.0 & $15 \mathrm{P} 1$ \\
\hline 61 & 19 & 20 & 3.83 & 1.07 & .69 & -.1 & .18 & -.5 & 1.42 & .24 & 95.0 & 95.0 & $61 \mathrm{P} 3$ \\
\hline 30 & 17 & 20 & 2.43 & .70 & .68 & -.8 & .34 & -.3 & k . .57 & .39 & 90.0 & 85.9 & $30 \mathrm{P} 1$ \\
\hline 77 & 13 & 20 & .94 & .56 & .68 & -1.3 & .50 & -.9 & j.71 & .53 & 90.0 & 76.7 & $77 \mathrm{L3}$ \\
\hline 35 & 15 & 20 & 1.61 & .60 & .67 & -1.2 & .42 & -.6 & i. 66 & .48 & 85.0 & 79.4 & $35 \mathrm{~L} 1$ \\
\hline 63 & 16 & 20 & 1.99 & .64 & .67 & -1.1 & .38 & -.5 & h.62 & .44 & 90.0 & 81.9 & 63P3 \\
\hline 56 & 9 & 20 & -.27 & .55 & .66 & -1.3 & .56 & -1.1 & g .75 & .57 & 90.0 & 76.2 & $56 \mathrm{~L} 2$ \\
\hline 81 & 16 & 20 & 1.99 & .64 & .66 & -1.1 & .39 & -.5 & f. 62 & .44 & 90.0 & 81.9 & 81P3 \\
\hline 78 & 16 & 20 & 1.99 & .64 & .62 & -1.2 & .36 & -.5 & e.64 & .44 & 90.0 & 81.9 & 78L3 \\
\hline 48 & 10 & 20 & .03 & .55 & .62 & -1.6 & .50 & -1.3 & d .77 & .57 & 95.0 & 75.7 & $48 \mathrm{~L} 2$ \\
\hline 73 & 13 & 20 & .94 & .56 & .60 & -1.7 & .44 & -1.0 & c .74 & .53 & 90.0 & 76.7 & $73 \mathrm{~L} 3$ \\
\hline 68 & 12 & 20 & .63 & .55 & .60 & -1.7 & .45 & -1.2 & b. .76 & .55 & 85.0 & 76.0 & 68L3 \\
\hline 19 & 15 & 20 & 1.61 & .60 & .57 & -1.7 & .36 & -.8 & a .70 & .48 & 95.0 & 79.4 & 19P1 \\
\hline MEAN & 14.5 & 20.0 & 1.67 & .71 & .99 & .1 & .90 & .1 & & & 81.5 & 82.1 & \\
\hline S.D & 3.8 & .0 & 1.50 & .27 & .29 & .9 & .73 & .8 & & & 10.3 & 6.0 & \\
\hline
\end{tabular}

Tabel di atas mengurutkan tingkat ketidaksesuaian dengan kriteria yang digunakan (outliers atau misfits) dengan mengacu pada kriteria yang akan digunakan untuk memeriksa kesesuaian jawaban yang tidak sesuai yaitu outfit mean square, outfit Z-standard, dan point measure correlation. Berdasarkah hasil output table Person Fit Order ada 3 (tiga) siswa yang dimana jawaban dari butir soal yang dikerjakan dinilai tidak fit, yaitu siswa dengan kode 54P2, 37L1, dan 32L1, ke_3 (tiga) siswa tersebut di luar batas kriteria tingkat kesesuaian.

Informasi jawaban dari butir soal yang tidak biasa ini bisa juga diketahui dengan cara melihat pada tabel skalogram atau biasa disebut matrik Guttman. Melalui matriks Guttman tersebut akan 
dapat memberikan informasi penyebab secara langsung, mengapa pola responnya tidak sesuai dengan kriteria.

Tabel 3. Guttman Scalogram of Responses

\begin{tabular}{|c|c|c|c|c|c|c|c|c|c|c|c|c|c|c|c|c|}
\hline & 1 & & & & & & & & 2 & & & & & & & \\
\hline & I & 8 & 15 & 5 & & 7 & 67 & 7 & $\begin{array}{ll}0 \quad 4 \\
0\end{array}$ & 1 & 29 & 9 & 36 & 3 & 90 & 4 \\
\hline & 1 & - & & & & & - & & & & 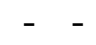 & & - & & & \\
\hline 3 & + & & 11 & 1 & & 1 & & & 1 & 1 & 11 & 1 & 11 & 1 & & \\
\hline 6 & 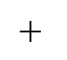 & 1 & 1 & & & & 1 & 1 & 1 & 1 & 1 & 1 & 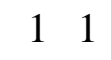 & & & \\
\hline 9 & + & 1 & 1 & 1 & & 1 & 1 & 1 & 1 & 1 & $\begin{array}{ll}1 & 1\end{array}$ & 1 & 1 & 1 & 1 & \\
\hline 2 & 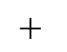 & 1 & 1 & & & 1 & 1 & & 1 & 1 & 11 & 11 & 1 & 1 & ) & \\
\hline 9 & 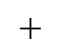 & 1 & 1 & 1 & & 1 & 1 & 1 & 1 & 1 & 11 & 1 & $\begin{array}{ll}1 & 1\end{array}$ & 1 & 11 & \\
\hline & 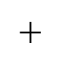 & 1 & 1 & 1 & & 1 & 1 & 1 & 1 & 1 & 11 & 11 & 11 & 1 & 11 & \\
\hline & + & 1 & 1 & 1 & 1 & 1 & 1 & & $\begin{array}{ll}1 & 1\end{array}$ & 1 & $\begin{array}{ll}1 & 1\end{array}$ & 11 & $\begin{array}{ll}1 & 1\end{array}$ & 1 & 10 & \\
\hline & + & 1 & 1 & 1 & & 1 & 1 & 1 & 10 & 1 & $\begin{array}{ll}1 & 1\end{array}$ & 11 & $\begin{array}{ll}1 & 1\end{array}$ & 1 & $\begin{array}{ll}1 & 1\end{array}$ & \\
\hline & + & 1 & 1 & 1 & & 1 & 1 & 1 & 1 & 1 & $\begin{array}{ll}1 & 1\end{array}$ & 11 & 11 & 1 & $\begin{array}{ll}1 & 1\end{array}$ & \\
\hline 1 & 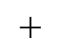 & & 1 & 1 & 1 & 1 & $\begin{array}{ll}1 & 1\end{array}$ & & 1 & 1 & $\begin{array}{ll}1 & 1\end{array}$ & 11 & $\begin{array}{ll}1 & 1\end{array}$ & 0 & 1 & \\
\hline 6 & + & 1 & 1 & 1 & 1 & 1 & 1 & 1 & $\begin{array}{ll}1 & 1\end{array}$ & 1 & $\begin{array}{ll}1 & 1\end{array}$ & 1 & 1 & 1 & $\begin{array}{ll}0 & 1\end{array}$ & \\
\hline & + & & 1 & 1 & 1 & 1 & $\begin{array}{ll}1 & 1\end{array}$ & 1 & $\begin{array}{ll}1 & 1\end{array}$ & 0 & $\begin{array}{ll}1 & 1\end{array}$ & 11 & 10 & 1 & $\begin{array}{ll}1 & 1\end{array}$ & \\
\hline & . & & 1 & & & 1 & 1 & 1 & 11 & 1 & $\begin{array}{ll}1 & 1\end{array}$ & 11 & $\begin{array}{ll}0 & 1\end{array}$ & 1 & 1 & \\
\hline & + & 1 & 1 & 1 & 1 & 1 & $\begin{array}{ll}1 & 1\end{array}$ & 1 & $\begin{array}{ll}1 & 1\end{array}$ & 1 & $\begin{array}{ll}1 & 1\end{array}$ & 0 & $\begin{array}{ll}1 & 1\end{array}$ & 1 & $\begin{array}{ll}1 & 1\end{array}$ & \\
\hline & + & 1 & 1 & 1 & 1 & 1 & $\begin{array}{ll}1 & 1\end{array}$ & 1 & $\begin{array}{ll}1 & 1\end{array}$ & 1 & $\begin{array}{ll}1 & 1\end{array}$ & 1 & $\begin{array}{ll}1 & 1\end{array}$ & 0 & $\begin{array}{ll}1 & 1\end{array}$ & \\
\hline & + & & 1 & 1 & & 1 & $\begin{array}{ll}1 & 1\end{array}$ & 1 & 1 & 1 & $\begin{array}{ll}1 & 1\end{array}$ & 1 & 10 & 1 & 1 & \\
\hline & + & & 1 & & & 1 & 11 & & 11 & 1 & $\begin{array}{ll}1 & 1\end{array}$ & 1 & 10 & 1 & 1 & \\
\hline & + & 1 & 1 & 1 & 1 & 1 & $\begin{array}{ll}1 & 1\end{array}$ & 1 & $\begin{array}{ll}1 & 1\end{array}$ & 1 & $\begin{array}{ll}1 & 1\end{array}$ & 1 & $\begin{array}{ll}1 & 1\end{array}$ & 1 & $\begin{array}{ll}0 & 0\end{array}$ & \\
\hline & + & 1 & 1 & 1 & 1 & 1 & 11 & 1 & 11 & 1 & 11 & 11 & 10 & 1 & 11 & \\
\hline & + & 1 & 1 & 1 & & 1 & 11 & 1 & $\begin{array}{ll}1 & 1\end{array}$ & 1 & 11 & 11 & $\begin{array}{ll}1 & 1\end{array}$ & 1 & $\begin{array}{ll}0 & 0\end{array}$ & \\
\hline I & 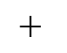 & & 1 & 1 & 1 & 1 & $\begin{array}{ll}1 & 1\end{array}$ & & $\begin{array}{ll}1 & 1\end{array}$ & 1 & $\begin{array}{ll}1 & 1\end{array}$ & 1 & $\begin{array}{ll}0 & 1\end{array}$ & 0 & $\begin{array}{ll}0 & 1\end{array}$ & \\
\hline & + & 1 & 1 & 1 & 1 & 1 & 1 & & 1 & 1 & $\begin{array}{ll}1 & 1\end{array}$ & 0 & $\begin{array}{ll}0 & 1\end{array}$ & 1 & $\begin{array}{ll}1 & 1\end{array}$ & \\
\hline & + & 1 & 1 & 1 & & 1 & 10 & & $\begin{array}{ll}1 & 1\end{array}$ & 1 & $\begin{array}{ll}0 & 1\end{array}$ & 10 & $\begin{array}{ll}1 & 1\end{array}$ & 1 & $\begin{array}{ll}1 & 1\end{array}$ & \\
\hline & + & & 1 & 1 & & 1 & 11 & & $\begin{array}{ll}11 \\
\text { L }\end{array}$ & 0 & 11 & 11 & $\begin{array}{ll}1 & 1\end{array}$ & 0 & 10 & \\
\hline & + & 1 & 1 & 1 & 1 & 1 & $\begin{array}{ll}1 & 1\end{array}$ & & $\begin{array}{ll}11\end{array}$ & 0 & 11 & . & 11 & 0 & 10 & \\
\hline & + & 1 & 1 & 1 & 1 & 1 & 10 & & $\begin{array}{ll}1 & 1\end{array}$ & 1 & $\begin{array}{ll}1 & 1\end{array}$ & 1 & $\begin{array}{ll}1 & 1\end{array}$ & 0 & $\begin{array}{ll}0 & 1\end{array}$ & \\
\hline & + & 1 & 1 & 1 & & 1 & 11 & & 11 & 1 & $\begin{array}{ll}1 & 1\end{array}$ & 1 & 11 & 0 & 1 & \\
\hline & + & 1 & 1 & 1 & 1 & 1 & 11 & & $\begin{array}{ll}1 & 1\end{array}$ & 1 & 10 & ) & $\begin{array}{ll}1 & 1\end{array}$ & 0 & 1 & \\
\hline & + & 1 & 1 & 1 & 1 & 1 & 1 & & $\begin{array}{ll}1 & 1\end{array}$ & 1 & $\begin{array}{ll}1 & 1\end{array}$ & 11 & $\begin{array}{ll}0 & 1\end{array}$ & 1 & $\begin{array}{ll}0 & 0\end{array}$ & \\
\hline & + & 1 & 1 & 1 & & 1 & 11 & & 11 & 1 & $\begin{array}{ll}0 & 1\end{array}$ & 10 & 11 & 1 & 11 & \\
\hline 5 & + & 1 & 1 & 1 & 1 & 1 & 11 & & $\begin{array}{ll}1 & 1\end{array}$ & 1 & $\begin{array}{ll}0 & 1\end{array}$ & 11 & $\begin{array}{ll}0 & 1\end{array}$ & 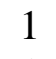 & $\begin{array}{ll}0 & 1\end{array}$ & \\
\hline 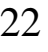 & + & 1 & 11 & 1 & 1 & 1 & $\begin{array}{ll}1 & 1\end{array}$ & & $\begin{array}{ll}1 & 1\end{array}$ & 1 & $\begin{array}{ll}1 & 1\end{array}$ & 11 & $\begin{array}{ll}0 & 0\end{array}$ & 1 & $\begin{array}{ll}0 & 1\end{array}$ & \\
\hline & + & 1 & 11 & 1 & & 1 & $\begin{array}{ll}1 & 1\end{array}$ & & $\begin{array}{ll}0 & 1\end{array}$ & 1 & $\begin{array}{ll}1 & 1\end{array}$ & 1 & 11 & 1 & $\begin{array}{ll}0 & 0\end{array}$ & \\
\hline & + & 1 & 1 & 1 & & 1 & $\begin{array}{ll}1 & 1\end{array}$ & & $\begin{array}{ll}0 & 1\end{array}$ & 1 & 10 & 1 & 11 & 0 & 10 & \\
\hline & + & 1 & 11 & 0 & 1 & 1 & $\begin{array}{ll}1 & 1\end{array}$ & & $\begin{array}{ll}0 & 1\end{array}$ & 1 & $\begin{array}{ll}1 & 1\end{array}$ & 1 & $\begin{array}{ll}0 & 1\end{array}$ & 0 & $\begin{array}{ll}1 & 1\end{array}$ & \\
\hline & + & & & 1 & 1 & 1 & $\begin{array}{ll}1 & 1\end{array}$ & & $\begin{array}{ll}1 & 1\end{array}$ & 1 & 10 & 1 & $\begin{array}{ll}0 & 1\end{array}$ & 0 & $\begin{array}{ll}1 & 1\end{array}$ & \\
\hline & + & 1 & 1 & 1 & & 1 & $\begin{array}{ll}1 & 1\end{array}$ & & $\begin{array}{ll}1 & 1\end{array}$ & 1 & $\begin{array}{ll}1 & 1\end{array}$ & 1 & 10 & 0 & 10 & \\
\hline & + & & 1 & 1 & 1 & 1 & 11 & & $\begin{array}{ll}1 & 1\end{array}$ & 1 & $\begin{array}{ll}1 & 1\end{array}$ & 1 & 1 & & $\begin{array}{ll}0 & 0\end{array}$ & \\
\hline 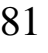 & + & & & 1 & 1 & 1 & 1 & & $\begin{array}{ll}1 & 1\end{array}$ & & $\begin{array}{ll}1 & 1\end{array}$ & & 11 & & 0 & \\
\hline 4 & + & & 11 & 1 & & 1 & $\begin{array}{ll}1 & 1\end{array}$ & & $\begin{array}{ll}1 & 1\end{array}$ & 1 & $\begin{array}{ll}0 & 0\end{array}$ & 1 & 11 & 1 & $\begin{array}{ll}0 & 0\end{array}$ & \\
\hline & + & 1 & 1 & 1 & & 1 & 1 & & $\begin{array}{ll}1 & 1\end{array}$ & & 11 & 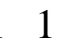 & 10 & & $\begin{array}{ll}0 & 1\end{array}$ & \\
\hline & + & & 1 & 0 & & 1 & 1 & & 1 & & 11 & ) & $\begin{array}{ll}1 & 1\end{array}$ & & 1 & \\
\hline & 1 & & & & & & & & & & & & 01 & & & \\
\hline
\end{tabular}




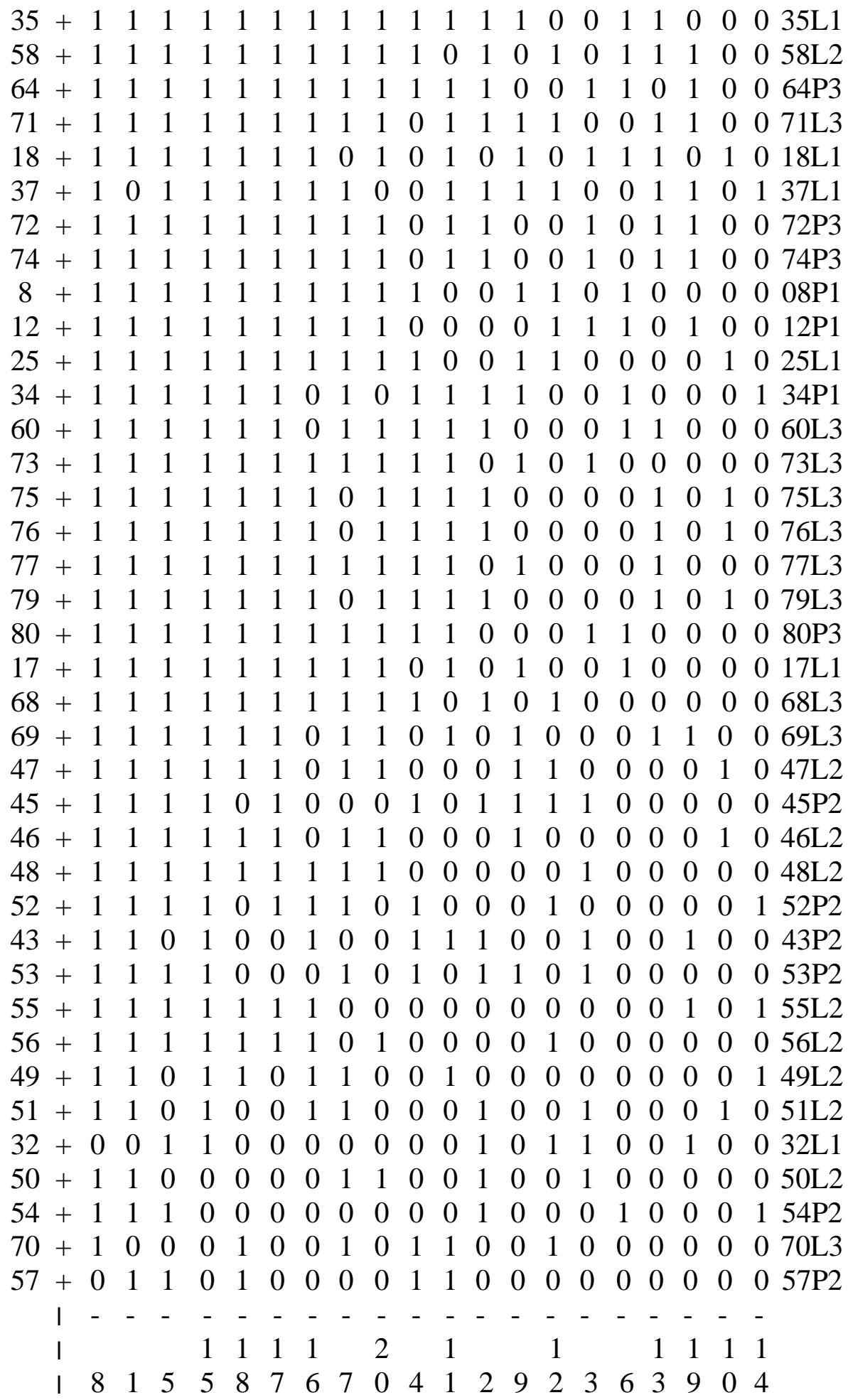

Keutamaan lain dari skalogram adalah bisa mendeteksi adanya ketidakcermatan (careless) ataupun adanya tebakan (lucky guess). Hal ini dapat dilihat pada tabel 3 di atas, hasil analisis menunjukkan adanya siswa kode 38L1, dan 14L1 termasuk pada kriteria siswa yang tidak cermat (careless), dimana jawaban pada butir soal termudah pada soal nomor 15 siswa tidak mampu mengerjakan butir soal secara benar, padahal jawaban pada butir soal yang lebih sulit siswa tersebut bisa mengerjakan yaitu pada soal nomor 14 . 
Selain itu, di samping tidak cermat (careless), terdeteksi siswa dalam mengerjakan soal terdapat adanya tebakan (lucky guess). Hal ini tampak pada tabel di atas, yaitu pada siswa kode 37L1, dimana pada soal nomor 1 siswa tersebut tidak mempu mengerjakan soal yang paling mudah, disisi lain siswa tersebut mampu mengerjakan soal yang sulit yaitu soal pada nomor 14, hal inilah yang mengindikasikan adanya tebakan pada jawaban siswa tersebut.

\section{KESIMPULAN}

Hasil analisis abilitas siswa pada tes Penilaian Akhir Semester mata pelajaran PAdB dengan menggunakan rasch model di SD Ma'arif NU Pandaan Pasuruan yaitu pertama, abilitas tinggi yaitu nomor 3 (tiga) atau kodenya 03P1 sedangkan abilitas paling rendah yaitu kode 57P2. Kedua, ada 3 (tiga) siswa yang pola jawabannya dinilai tidak fit yaitu pada siswa dengan kode 54P2, 37L1, dan 32L1, ke-3 (tiga) siswa tersebut di luar batas kriteria tingkat kesesuaian. Selain itu siswa kode (38L1, 14L1), di samping tidak cermat (careless), terdeteksi siswa dalam mengerjakan soal terdapat adanya tebakan (lucky guess). Hal ini tampak pada tabel di atas, yaitu pada siswa kode 37L1, di mana pada soal nomor 1 siswa tersebut tidak mempu mengerjakan soal yang paling mudah, disisi lain siswa tersebut mampu mengerjakan soal yang sulit yaitu soal pada nomor 14.

\section{DAFTAR PUSTAKA}

Bambang Sumintono dan Wahyu Widhiarso. (2015). Aplikasi pemodelan Rasch: pada assessment pendidikan. Trim komunikata.

Boone, W. J., Staver, J. R., \& Yale, M. S. (2013). Rasch analysis in the human sciences. Springer.

Kirom, A., \& Hasyim, M. (2021). MENGGUNAKAN PENDEKATAN RASCH MODEL DI SD MA' ARIF NU KECAMATAN PANDAAN PASURUAN. 2(2), 92-98.

Maruti, I. M. dan E. S. (2016). Evaluasi Pendidikan. CV. AE Media Grafika.

Rivale, M. T. dan W. (2019). Penilaian. PGRI Prov Kalbar. 